\title{
Geothermal Systems Characteristics in Pesanggrahan Area, Bawang Distric, Batang Regency, Based on Geology and Geochemistry Analysis
}

\author{
Rakhmadi Sulistyanto*1, Udi Harmoko ${ }^{1}$, and Gatot Yuliyanto ${ }^{1}$ \\ ${ }^{1}$ Master Program of Energy, School of Postgraduate Studies, Diponegoro University, Semarang - Indonesia
}

\begin{abstract}
Research conducted at Pesanggrahan area, Sangubanyu Village, Bawang District, Batang Regency with geographical coordinates at 7०5'00 "00 S - 77'30" $00 \mathrm{~S}$, and $109^{\circ} 56^{\prime} 00$ "E-109 $58^{\prime} 30^{\prime \prime E}$, with an area of around $25 \mathrm{Km}^{2}$. Research methods used quantitative and qualitative methods with descriptive analysis, geological and geochemical analysis. Geochemical fluid samples were taken in manifestations hot springs Pesanggrahan and hot water samples in Sibanteng and Sileri Crater to determine the relationship with geothermal systems in this area. Geomorphology divided into two geomorphology units, they are steep slope and sloping hill. Stratigraphy can be divided into three lithologies, which are andesite breccia, tuff breccia, and tuff sandstone. Based on fluid geochemical characteristics of manifestations, it can be interpreted that hot spring of Pesanggrahan area is outflow zone with bicarbonate-chloride water type, Sibanteng Crater and Sileri Crater, include upflow zone with water type sulfate for Sibanteng Crater, bicarbonate-sulfide water type for Sileri Crater. Environmental source geothermal fluid Pesanggrahan from the magmatic volcanic process. Sources geothermal fluid in Pesanggrahan, Sibanteng and Sileri Crater from meteoric water. Estimated temperature Pesanggrahan in the interval $50-100^{\circ} \mathrm{C}$, Sileri Craters $160-180^{\circ} \mathrm{C}$, and Sibanteng Craters $140-150^{\circ} \mathrm{C}$. The Conceptual model of Pesanggrahan includes a geothermal system that associated with volcanic system and high relief liquid dominated system.
\end{abstract}

Keyword: geothermal system; manifestation; geochemical; conceptual model.

\section{Introduction}

Research conducted at Pesanggrahan area, located in Sangubanyu Village, Bawang District, Batang Regency at the geographical coordinates at $7^{\circ} 5^{\prime} 00 " 00 \mathrm{~S}-7^{\circ}$ 7'30" $00 \mathrm{~S}$, and $109^{\circ} 56^{\prime} 00$ "E- $109^{\circ} 58^{\prime} 30$ "E, with an area of around $25 \mathrm{Km}^{2}$, which is physiography regional including North Serayu Mountain zone [1].

The objective of this research activity to be determined the geothermal system Pesanggrahan area, water type fluid hydrothermal, source of geothermal fluid system, correlation geothermal system Pesanggrahan area with a geothermal system Dieng area and conceptual model of geothermal system Pesanggrahan area

\section{Research Method}

The study was conducted using quantitative and qualitative methods with descriptive analysis, geological and geochemical analysis for conceptual of geothermal system models. Sources of data in this research, using primary and secondary data. Primary data were taken in the area of research geological and geochemistry data such as lithology, structural geology, geomorphology, and stratigraphy. Geochemical data originated from samples of hot spring water, isotopes, meteorite groundwater, hot water temperature and using gas data sample if sulfatara manifestations were founded, while secondary data got from literature studies in regional geological data and previous research journals in the study area.

Geology and geochemistry mapping at Pesanggrahan geothermal areas are conducted to known stratigraphy, lithology, and structural geology at around manifestations, by mapping outcrops of igneous rock, sedimentary rocks, and measuring data on geological structure information. Geochemistry mapping survey was done by taken samples of hot water, and gas to a known pattern of fluid flow, temperature and type of hydrothermal fluids, combined with geological data can make beginning of manual to determine characteristics of geothermal system Pesanggrahan area.

\footnotetext{
*Corresponding author: rakhmadi_geo99@yahoo.com
} 


\section{Results and Discussion}

\subsection{Geomorphology}

Based on the morphometric, and morphogenetic aspects analyzed from digital elevation model and slope map, research area can be divided into two geomorphological units, namely: steep sloping geomorphological unit that spreads in most of south and north with an area of about $55 \%$ and sloping hillside geomorphological units occupies most of the northern part of the research area with an area of about $45 \%$ (Fig. 1.)

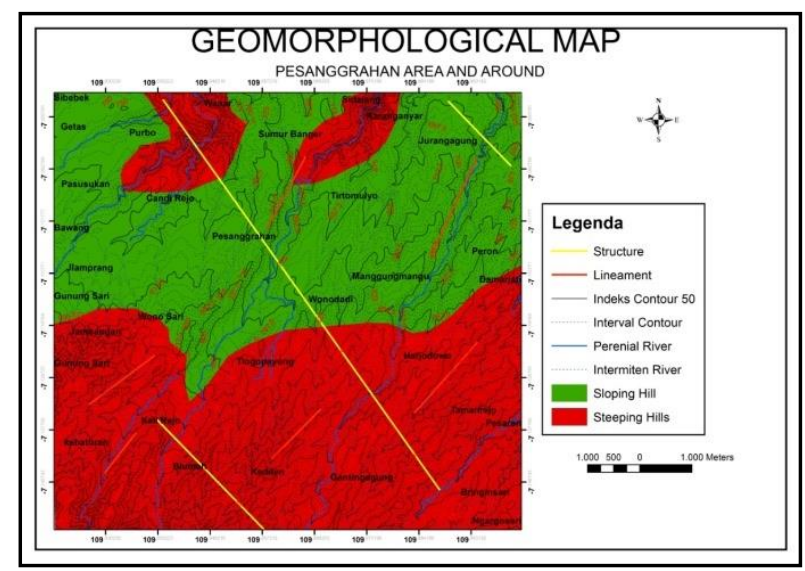

Fig.1. Geomorphology Map Pesanggrahan Area

\subsection{Stratigraphy}

Based on field data observations and secondary data, lithology in the study area can be divided into three lithologies with order from old to young age (Fig. 2.), namely Breccia Andesite, dominant spread in the north and west with an area of about $30 \%$ of the area, Breccia Tuff is spread almost throughout study area about 55\% area, and Sandstone Tuff spread in the northern part of approximately $15 \%$ area.

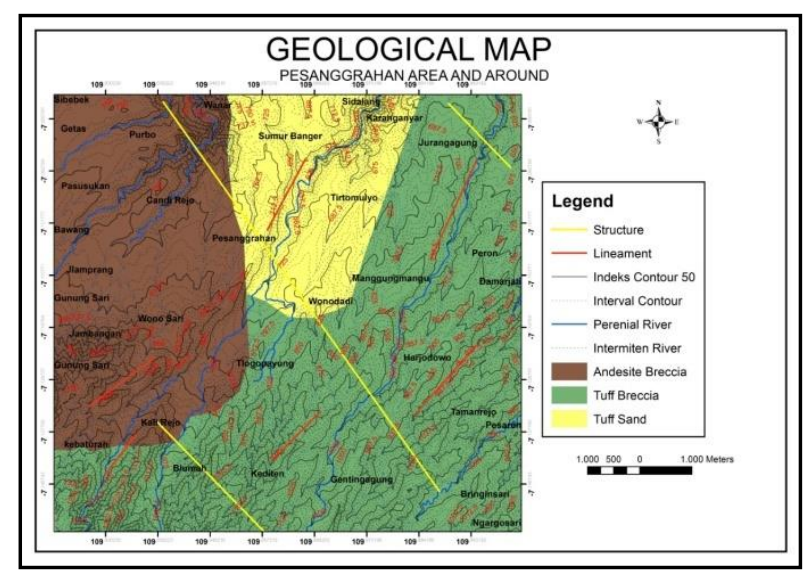

Fig. 2. Geology Map Pesanggrahan Area

\subsection{Geochemical Characteristics}

\subsubsection{Geothermal Manifestations}

Geothermal manifestations of Pesanggrahan area in the hot springs are located in several locations, location of hot springs pools, Plantungan area, and the Lampir river, Sangubanyu village, as shown in the map of structural manifestations in Fig. 3. This hot spring pool is used as a geotourist location by surrounding people in Batang Regency. The appearance of these four hot springs can be used as a clue to the existence of geothermal systems around this area.

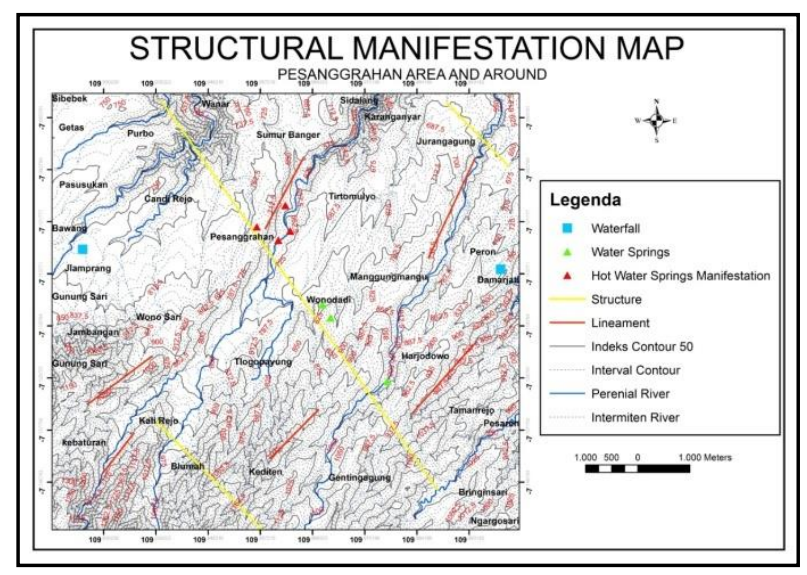

Fig. 3. Structural Manifestation Map Pesanggrahan Area

\subsubsection{Geothermal Fluid Type}

Based on the triangle diagram $\mathrm{Cl}-\mathrm{HCO}_{3}-$ $\mathrm{SO}_{4}$ (Giggenbach, 1988) in Figure 4, hot spring Pesanggrahan included in Chloride - Bicarbonate type water. A significant element of bicarbonate is indication of the outflow zone. Sileri crater manifestations include bicarbonate-sulfate type water. This spring had a concentration of $\mathrm{HCO}_{3}$. and $\mathrm{SO}_{4}$ which is relatively same value. These fluids include steamed waters which indicate mixing between the sulfide fluid from southern part of upflow zone geothermal Dieng system which is a high concentration in sulfate and chloride ions with meteoric water which high concentration in bicarbonate ions near the surface.

Manifestation of the Sibanteng crater so that it is classified as sulfate type water because of high $\mathrm{SO}_{4}$ concentration. This fluid including volcanic waters that indicated a mixture of chloride and sulfate water at a certain depth or can be created as a result of oxidation of $\mathrm{H}_{2} \mathrm{~S}$ in chloride water near surface in the discharge area. Sulfate water is usually found at boundary of area and near main upflow zone area. 


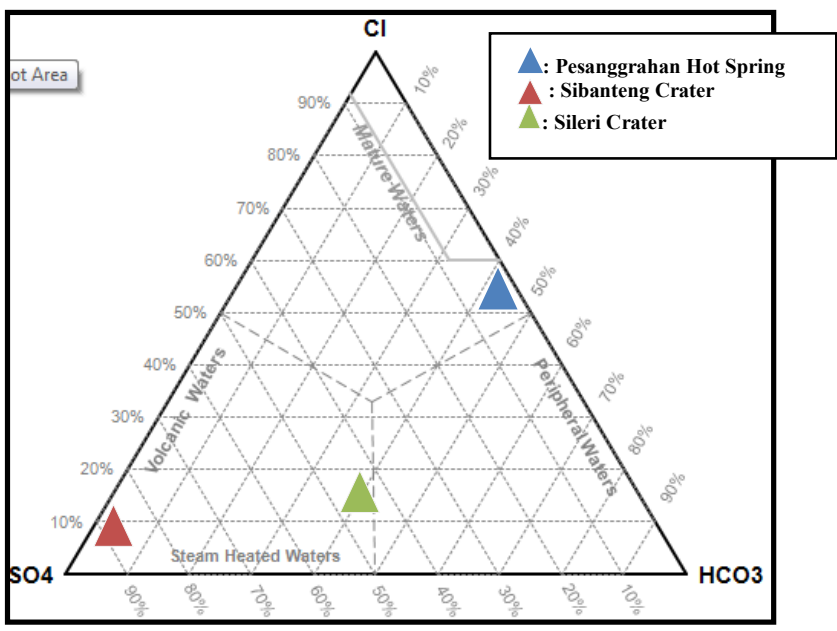

Fig. 4. Ternary Diagram $\mathrm{Cl}-\mathrm{HCO}_{3}-\mathrm{SO}_{4}$ Pesanggrahan Area

\subsubsection{Environment Origin Geothermal Fluid}

Based on the triangle diagram $\mathrm{Cl}-\mathrm{Li}-\mathrm{B}$ in Fig.5., Pesanggrahan hot springs, Sibanteng craters, and Sileri craters have a relatively low Lithium value $(<5 \%)$ and significant chloride and Boron concentration. Element value of chloride $(\mathrm{Cl})$ which is quite significant indicates that fluid of this manifestation comes from magmatic volcanic processes with ultramafic rocks carry dissolved $\mathrm{HCl}$ gas and $\mathrm{H}_{2} \mathrm{~S}$, which caused high chloride $(\mathrm{Cl})$ concentration. The percentage of Boron elements is relatively moderate, that is indicated the Boron element enrichment process in manifestation of hot water on the surface because interaction of hydrothermal fluid during transportation to surface with sedimentary rocks that are rich in organic matter.

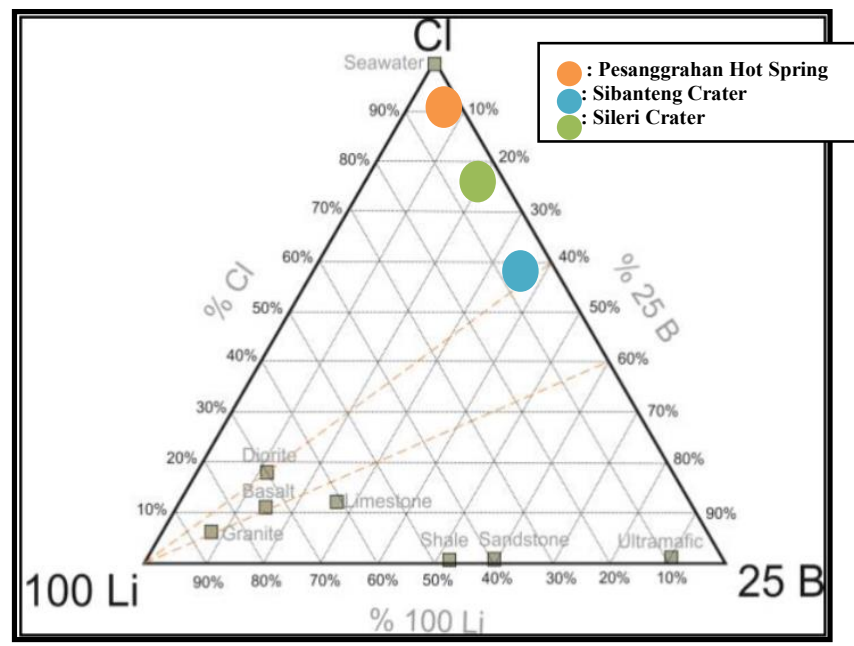

Fig. 5. Ternary Diagram Cl - Li - B Pesanggrahan Area

\subsection{Origin and Fluid Type Pesanggrahan}

Analysis of stable isotopes ${ }^{2} \mathrm{H}$ (D) and ${ }^{18} \mathrm{O}$ in geothermal systems is to evaluate the origin of geothermal fluids. Isotope samples were obtained from hot springs of Pesanggrahan, Sibanteng Crater and Sileri Crater. Data on isotope results analyzed at
Central Mineral and Geothermal Resources laboratory in Bandung can be seen in Table 1. Isotope data is plotted at graphic of determining geothermal water sources [2].

Table 1. Isotop D dan ${ }^{18} \mathrm{O}$ Manifestation Pesanggrahan Area

\begin{tabular}{|c|r|r|}
\hline SAMPLE & \multicolumn{1}{|c|}{$\mathrm{D} \_\mathrm{H}^{18}$} & $\square^{18} \mathrm{O}_{-}{ }^{16} \mathrm{O}$ \\
\hline Pesanggrahan Hot Spring & -41.49 & -6.23 \\
\hline Sibanteng Crater & -31.10 & -0.52 \\
\hline Sileri Crater & -43.41 & -4.11 \\
\hline
\end{tabular}

Results of the isotope plot in graphic determining Pesanggrahan hot springs, Sibanteng Crater and Sileri Kawah, it can be concluded in general that three hot springs are from meteoric water (Fig. 6.). This can be seen from the position of plotting three stable isotope samples close to the meteoric water line. Position of Sibanteng Crater and Sileri Crater has a value of isotope ${ }^{18} \mathrm{O}$ which is relatively greater due to hydrothermal process that occurs below the surface. Hot spring Pesanggrahan had very low value isotope ${ }^{18} \mathrm{O}$, with position plot more close to a meteoric water line, which indicates that interaction of the hydrothermal fluid with meteoric water has been very dominant. Three isotopes had difference results because of Pesanggrahan hot springs located on topography more sloping than Sibanteng Crater and Sileri Crater.

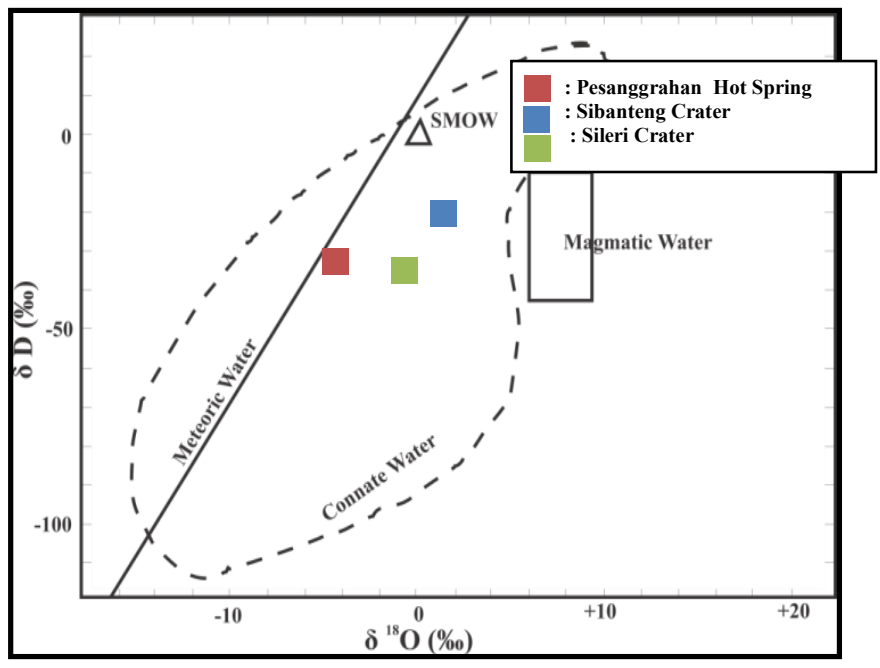

Fig. 6. Graphic Fluid Type Pesanggrahan Area

\subsection{Geotermometer Na-K-Mg}

Fig. 7, shows that results plotting hot spring Pesanggrahan area estimated had reservoir temperatures with a range around $50-100^{\circ} \mathrm{C}$, Sileri craters about $160-180^{\circ} \mathrm{C}$, and Sibanteng craters about $140-150^{\circ} \mathrm{C}$. Besides that, it can be seen that Pesanggrahan hot springs and Sileri crater are included in full equilibrium while the Sibanteng crater enters the margin of partial equilibrium near full equilibrium. This shows an indication that the fluid originates from the reservoir and may have interacted with meteoric 
water, partial equilibrium still reflects the fluid nature of the reservoir. Fluid condition is getting closer tonposition of full equilibrium indicates that the fluid is getting close to the reservoir so that less dilution, mixing, and reaction process with the rock.

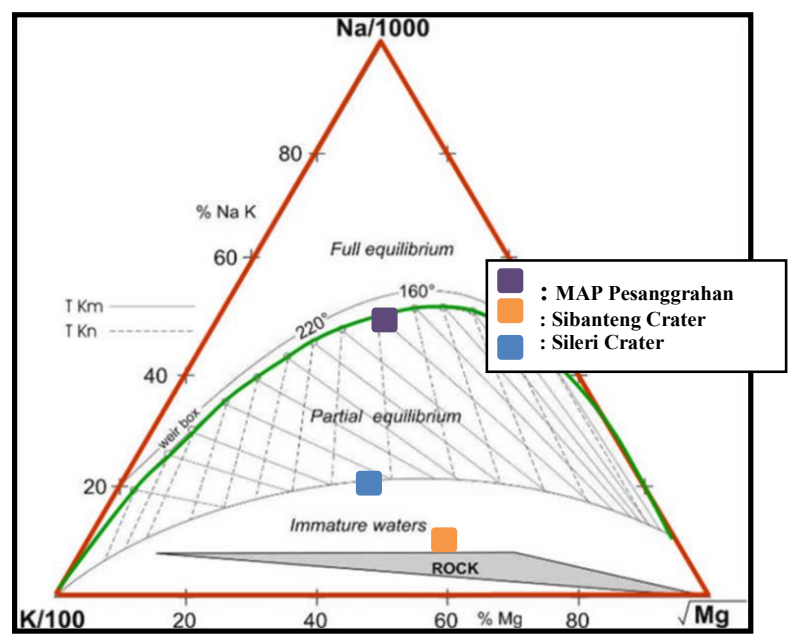

Fig. 7. Ternary Diagram Pesanggrahan Area

\subsection{Conceptual Model of Pesanggrahan Geothermal System}

Based on field conditions, all three manifestations were found around the old cone caldera of multi-cone mountain phreatic craters such as Sibanteng Crater and Sileri crater so that included in geothermal systems associated with volcanic systems [3] and high relief liquid dominated system [2]. The type of volcanic geothermal system is generally associated with quarterly volcanic activity and has magmatic heat sources.

Based on tfluid geochemical characteristics of manifestations and their distribution can be interpreted that hot spring Pesanggrahan area is an outflow zone characterized by bicarbonate-chloride water type. Sibanteng crater and Sileri Dieng crater include upflow zone which is characterized by sulfate water type for Sibanteng crater, a bicarbonate-sulfide water type. (Fig. 8.)

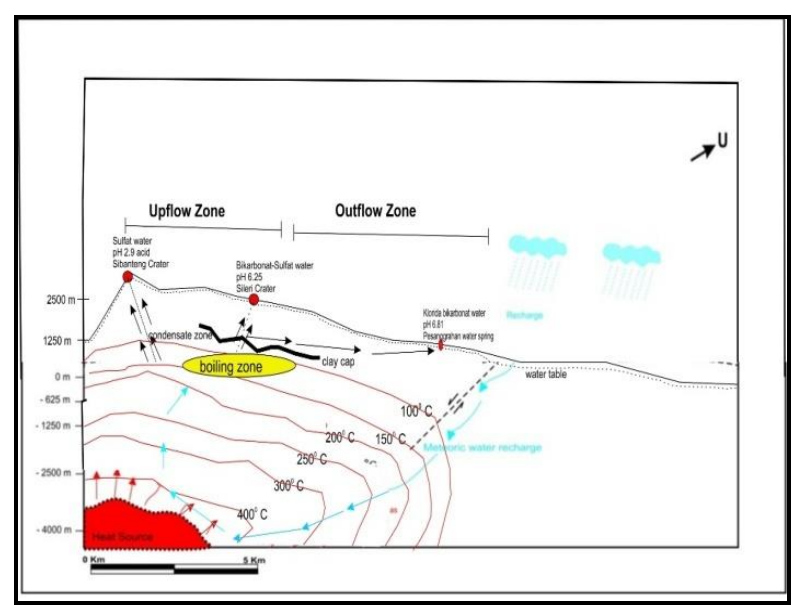

Fig.8. The conceptual model of Pesanggrahan geothermal system

\section{Conclusion}

Based on the fluid geochemical characteristics of manifestations and their distribution it can be interpreted that hot spring Pesanggrahan area is an outflow zone characterized by bicarbonate-chloride water type. Sibanteng crater and Sileri crater include upflow zone which is characterized by sulfate water type for Sibanteng crater, bicarbonate-sulfide water.

Geothermal fluid environment Pesanggrahan origin suspected from reservoir and source rocks are same that of volcanic magmatic with ultramafic rocks that base on interpretation of geochemical ratio $\mathrm{B} / \mathrm{Cl}$ and $\mathrm{Cl}$ triangular diagram $\mathrm{Cl}-\mathrm{Li}-\mathrm{B}$. Based on the analysis of stable isotope samples in geothermal water, sources of geothermal fluid hot springs in Pesanggrahan, Sibanteng and Sileri craters are from meteoric water which reacted with hydrothermal fluid. Estimates of temperature based on geothermometer $\mathrm{Na}-\mathrm{K}-\mathrm{Mg}$, hot springs Pesanggrahan area estimated reservoir temperatures in a range of about $50-100^{\circ} \mathrm{C}$, Sileri crater about $160-180^{\circ} \mathrm{C}$, and Sibanteng crater about 140 $150^{\circ} \mathrm{C}$. Conceptual model of Pesanggrahan geothermal system is included in a geothermal system that is associated with a volcanic system and high relief liquid dominated system [2].

\section{References}

1. Bemmelen, V. R.W., (1949). The Geology of Indonesia Vol. I A, The Hague. Netherlands

2. K. Nicholson, Geothermal Fluids: Chemistry and Exploration Techniques, Berlin: Springer-Verlag Inc. (1993)

3. Kasbani, Type of Geothermal System in Indonesia and Its Estimated Potential Energy, Kelompok Program Penelitian Panasbumi, PMG- Badan Geologi (2009) 